\title{
THE LANGUAGE OF VITICULTURE IN ESP. VOCABULARY TEACHING TECHNIQUES FOR HORTICULTURE STUDENTS
}

\author{
Olivia Chirobocea-Tudor
}

Faculty of Letters, "Ovidius" University of Constanta, Romania

\begin{abstract}
English is a useful and necessary tool for any ESP student and so too horticulture students will need English in their future careers. Therefore, being able to communicate effectively and use the language in their field appropriately will help their business and increase their level of professionalism. This article will explore various techniques for the teaching of specialized horticultural vocabulary, in particular the terminological aspects of viticulture and viniculture which together form an important and widespread branch of horticulture with high degree of internationalization, given the rising popularity of wine and grape growing around the world. While each branch of ESP deals with its own unique features, so too English for horticulture and its subdivision, viticulture, has its own challenges in terms of vocabulary, of the equivalence between L1 and English and of usage. This article will analyze such particularities and explore ways in which various levels of specialized vocabulary can be taught to students in an engaging and effective manner.
\end{abstract}

Keywords: ESP, vocabulary, viticulture, horticulture

\footnotetext{
About the author: Olivia Chirobocea-Tudor is an associate professor at "Ovidius" University of Constanta, Faculty of Letters. She teaches English for Specific Purposes in the field of natural sciences, but her area of research is wider including cultural studies and American literature (doctoral studies). She published several English courses for students, a specialized bilingual dictionary and numerous articles on topics related to ESP, terminology, as well as cultural studies and American postmodernist literature. She was also a member in six research projects between 2007 and 2020, and edited the proceedings volumes of five national and international conferences. She is a member in several professional associations in the field of philology.

e-mail:olivia.ch31@gmail.com; chirobocea.olivia@365.univ-ovidius.ro
}

ORCID iD: https://orcid.org/0000-0002-2850-3094

Copyright (C) 2021 Olivia Chirobocea-Tudor

Article history: Received: 21 April 2021; Reviewed: 16 July 2021; Revised: 09 August 2021; Accepted: 17 August 2021; Published: 31 August 2021

This open access article is published and distributed under a Creative Commons Attribution 4.0 International License.

Citation (APA): Chirobocea-Tudor, O. (2021). The language of viticulture in ESP. Vocabulary teaching techniques for horticulture students. Studies in Linguistics, Culture, and FLT, 9(2), 64-83. https://doi. org/10.46687/WMLH2497 


\section{Introduction}

The large amount of ESP research has proven many times over that vocabulary teaching and learning is one of the most important aspects of ESP alongside the development of the four basic skills; in fact, it is the underlying component on which the skills can be developed (Khazaal, 2019), the "foundation upon which to build the overall language proficiency" (Costeleanu, 2019, p. 1001). Vocabulary acquisition is essential in ESP because it helps learners understand the language and ideas of their own field of activity (Woodward-Kron, 2008, p. 246; Coxhead, 2013, p. 116; Brooks, 2014, p. 153). Knowledge of vocabulary (technical or domain-specific as well as general) is among the top requirements for successful communication in a professional environment (Gatehouse, 2001; Adam et al., 2013, p. 427).

\section{Context and specific issues}

My own experience has been with the students enrolled in the Horticulture program at "Ovidius" University of Constanta (Romania). They study for four years for their bachelor degree and their curriculum includes disciplines such as olericulture, pomology, viticulture and enology, landscaping and arboriculture. However, these staple disciplines, which also comprise most of the fundamental horticultural terminology, are studied in the third and fourth year, while English for specific purposes is studied in the first and second year. This imbalance poses some difficulties because the students are not yet aware of most of the important concepts specific to horticulture, therefore it is sometimes the task of the English teacher to disambiguate the terminology both in L1 and L2. In the first and second year the disciplines in their curriculum include topics that constitute the basis for what is to come, namely botany and plant physiology, pedology, farming machinery, microbiology, biochemistry, phytopathology, entomology, agrochemistry and genetics. This curriculum that stretches over the four years of study establishes the basis of the terminology they should be familiar with, both in L1 and L2.

The ESP class is allotted two hours per week for four semesters, but whether such a complex vocabulary can be covered in this time depends to a large extent on the students and their level of proficiency. Their knowledge varies from generation to generation, but there is a general consistency in that the students can usually be ranked in the lower-intermediate level with few intermediateadvanced peaks. This poses difficulties to the teaching of specialized vocabulary because the learners do not have good knowledge of the general English vocabulary recommended by West's 1953 General Service List or its recent updates in 2013 by Brezina \& Gablasova (Brezina \& Gablasova, 2015) as well as Browne, Culligan and Phillips (Browne, 2013). Thus, the ESP teacher must adapt to both students' proficiency level and specialized knowledge in order 
to produce a successful teaching experience. Unfortunately, when the level of proficiency is too low, the amount of specialized vocabulary to be taught is much diminished by the fact that the students first need to fill their gaps in general vocabulary (Kavaliauskienë \& Janulevièienë, 2000), a regrettable situation often encountered in ESP. It is therefore more important for the ESP teacher to teach the students how to detect and learn the terminology in the future, outside the English class, to offer them useful tools in this regard and encourage critical thinking.

\section{Needs analysis}

In terms of needs analysis, this should always be the basic step before designing ESP materials because it indicates both what the learners already possess (proficiency level, motivation) and what they want to achieve (Vulić, 2013, p. 866). This is a necessary step because the ESP class should respond to the learners' needs (Dudley-Evans \& St John, 1998, p. 4) and should prepare them to face future professional environments (Kovács, 2011). In an academic context, needs analysis renders rather mixed results because the students have a wide variety of options in their future careers, therefore their needs are quite complex as a result. The ESP teacher must therefore cover a wide range of skills and knowledge. Sometimes, students are not the best source of information for needs analysis because not all their motives are straightforward and they are not aware of all the possibilities they may face when they graduate. Very often, depending on the domain of study, they are also not very interested in learning a foreign language, English as it is often the case, because they do not see themselves needing this tool in their future careers. In the case of programs such as agriculture or horticulture, the students' reasons for choosing to enroll should be very obvious and still sometimes they are not. Some are pushed by their parents because of a family business or because they believe there is a future in this occupation, others chose it because they failed the admission test to a different program, others simply like flowers and decide to see how it goes. About half do not have very clear targets for their future therefore it can be difficult to engage them by using the usual ESP means. These opinions have been identified as a result of questionnaires or discussions with the students at the beginning of their academic life and have been consistent over the years.

Therefore, it is often better to include in needs analysis the opinions of teachers, graduate students and other people who work in the field in order to understand what careers in horticulture might involve, should the students actually choose to follow this path. Given that horticulture graduates can work as experts, advisers, inspectors, managers, researchers or even public servants or teachers in the field, they may need a variety of advanced English language skills depending on their range of activities. Receptive skills (reading and listening) are used 
for gathering information by reading articles, textbooks, procedure, guides, brochures, posters, emails or by listening to speeches by various specialists in their field at conferences or symposia. The productive skills (writing and speaking) are used for communication with other professionals by writing emails or by speaking directly at conferences, symposia, farming and food fairs and shows, by writing speeches or presentations and speaking in public or private, making connections with possible business partners, farmers and other professionals in the field.

The domains of viticulture, winemaking and enology are particularly prone to such effervescence illustrated by the many activities mentioned previously because of their high degree of internationalization, given the rising popularity of wine and grape growing around the world. Therefore, horticulture graduates that decide to follow this path may have even more need of English if they are to grow their venture and connect with professionals from other countries in the viticulture, wine or even hospitality business. Hiring a full-time translator may be expensive for a small business or for someone just starting their vineyard or wine venture, therefore possessing basic English skills (Kadagidze \& Tskhvitava, 2015, p.16) and knowledge of essential terminology is imperative. While very few, if any, are likely to choose the academic avenue and continue solely as researchers, if the students decide to work as horticultural engineers, grape growers or enologists they will still need to understand the academic vocabulary when they need to read articles about the state-of-the-art in horticulture, therefore elements of this type of vocabulary are also required.

\section{Terminology issues}

Viticulture and winemaking are rather multilingual domains. Given that the tradition of grape growing was perfected and popularized in France, there is a lot of French terminology related to the cultivation of the grapevine that is still used as such even in English, but the terms also have an Anglo-Saxon equivalent (e.g. veraison $=$ onset of grape ripening, barrique $=$ barrel (2251), millerandage $=$ shot berries, négociant $=$ trader or wine merchant, vigneron $=$ grape grower, sur lie $=$ on the lees). While the French may have precedence in naming stages and other concepts related to grape growing and winemaking, there are other languages that offer their contribution to these complex domains such as Italian and even German. However, given that English has become lingua franca in practically all fields of activity, doubled by the fact that English-speaking countries such as the United States of America, Australia, New Zealand or South Africa have gained much notoriety in the wine business over the past few decades (MacNeil, 2015), English has also become the language of communication in this niche domain as well. Enologists and winemakers are hired by wineries all over the world, wine tasters but also grape growers travel to a variety of countries to 
participate in wine shows, wine tasting events but also scientific conferences and gatherings in order to stay up to date with the latest discoveries in the field. There is a considerable amount of reading material online, from scientific articles to the acclaimed wine magazines that are well-known in this field, not to mention the many films, documentaries or short videos that can also be found online. All these are written or spoken in English for full accessibility to anyone, whether novice or expert, amateur or professional.

If we are to take all these into account, the terminology that students should become familiar with, just for this branch of horticulture, is immense. However, the ESP class must also include the terminology of the other branches mentioned previously. The good news is that many elements related to the grapevine plant itself, as well as its cultivation, are common to other crops such fruit trees, for example. Thus, the basic parts of the plant are the same (root, stem/trunk, shoot, bud, leaf, flower etc.) and the differences will be emphasized (graft union, arm, cordon, cane, spur, berry etc.). Also, the basic cultivation techniques are similar (terms related to soil type, weather conditions, types of plant propagation, planting, irrigation, fertilization, pruning, training, pest control, harvesting etc.) and again the differences can be emphasized for each of these stages. Most of the major differences, however, occur after harvesting, in the winemaking process with its specific stages and technology. Still, depending on the learners' level, a selection should be made as there is no need to insist on highly specific terminology that may be rarely encountered in a more general horticultural context. The meaning of such terms can be determined once the learners' skills improve and they are more knowledgeable of their own field as well. Thus, terms such as crown gall (disease), riddling (procedure), tastevin (object) and the wide range of complicated chemicals that are contained in wine will not necessarily be encountered by horticulturists in their everyday activities, but may be encountered more often by those directly involved in this particular branch, namely viticulture and winemaking.

Given the limited time and other impediments, it is therefore more important to teach students cognates, defined as words with similar form in two different languages (Atkinson, 1993, p. 59), and distinguish them from non-cognates (Dudley-Evans \& St John, 1998, p. 81), word families (Costeleanu, 2019, p. 1000), how to differentiate among the main parts of speech and thus how to recognize and use appropriately nouns, verbs, adjectives but also pronouns, adverbs, prepositions and conjunctions. The students should also be encouraged to become more selective and critical in their searching and usage of correct English equivalents for Romanian terms, and should also be taught how to identify correctly the meaning and L1/L2 equivalents of those ordinary everyday words that "can carry very specific meanings in particular contexts" (Coxhead, 2013, p. 116). The difficult skill of recognizing and using collocations, which are very often encountered in specialized vocabulary (Kadagidze \& Tskhvitava, 2015, 
p. 15), is one of the most important tasks of the ESP teacher (Kavaliauskienë \& Janulevièienë, 2000), and this in fact refers to probably the most suitable method to be applied in ESP (Xhaferi, 2009), namely the lexical approach introduced by Michael Lewis who connects fluency to the amount of "prefabricated items" (Lewis, 1997, p. 15) or chunks of language a learner can acquire.

Here are some examples of the types of terms mentioned previously that can be found in viticulture and winemaking:

Cognates. This category includes most chemical processes involved in winemaking and chemicals found in must or wine, which are orthographically and phonetically similar in Romanian and English (anthocyanin = antocianină, biotin = biotină, dextran = dextran, ethyl = etil, flavonoid = flavonoidă, galactan $=$ galactan, hexose $=$ hexoză , inhibitor $=$ inhibitor, lactone $=$ lactonă, malic acid $=$ acid malic, oxide $=$ oxid, peptide $=$ peptidă, phenol $=$ fenol, resveratrol $=$ resveratrol, sterol $=$ sterol, tannin $=$ tanin, vinification $=$ vinificare etc.) as well as other terms, for example those related to botany and plant physiology (anthesis $=$ anteză, filament $=$ filament, internode $=$ internod, lobe $=l o b$, pedicel = pedicel, rachis $=$ rahis etc.).

Words with specific meaning in specific contexts. Terms such as bladder, bleeding, eye, legs, meniscus, skin, vein, tears are specific to human anatomy but can be encountered in viticulture and winemaking with other meanings, although related to some extent. For example, bleeding in human anatomy refers to a hemorrhage, the flow of blood from a wound, from a ruptured blood vessel. The Romanian equivalent in this case is sângerare. In the case of grapevine, bleeding similarly occurs when the vessels that transport the sap (which can be equated to blood in the case of plants) are cut during the spring pruning of the vine. However, the Romanian equivalent in this case is no longer sângerare but plâns which means crying in English, most likely due to the transparent aspect of the sap, similar to tears. Similar explanations can be given for the other terms mentioned and many others such as crown, chimera, blade, dumb, mute, spur, sucker, thief, turbulence, etc. The students should be made to understand that the first or most common equivalent they may find for a term may not be the one normally used in L1 or L2 in that particular context. They should be careful and check in order to use the terminology correctly so as to avoid confusion as well as appear unprofessional.

Word families. Nominalization, usually by derivational morphology, is often encountered in agriculture as a whole as well as horticulture and the branches we are dealing with, viticulture and winemaking. For example, the addition of the suffix -ing often creates words designating actions, processes, techniques or procedures: to graft $\rightarrow$ grafting, to prune $\rightarrow$ pruning, to stake $\rightarrow$ staking, to trellis $\rightarrow$ trellising, to train $\rightarrow$ training, to thin $\rightarrow$ thinning, to process $\rightarrow$ processing, to press $\rightarrow$ pressing, to fine $\rightarrow$ fining, to bottle $\rightarrow$ bottling, to blend 
$\rightarrow$ blending, to rack $\rightarrow$ racking, etc. This device makes it easy for the teacher to draw the students' attention to the differences among words within families as well as usage. Many other families of words are worth emphasizing, for example to ripen-ripe-ripening, which students always confuse and which is generally encountered in horticulture.

Collocations. As specified previously, collocations are a staple in specialized language, and viticulture and winemaking are no exception. The term wine alone collocates with dozens of words and here are a few examples:

\begin{tabular}{|c|c|c|c|}
\hline wine + noun & noun + wine & adjective + wine & verb + wine \\
\hline wine acidity & & botrytized wine & \\
\hline wine barrel & & cloudy wine & \\
\hline wine bottle & box wine & dry wine & to bottle wine \\
\hline wine cellar & Burgundy wine & fortified wine & to clarify wine \\
\hline wine chemistry & country wine & French wine & to drink wine \\
\hline wine drinker & dessert wine & organic wine & to fine wine \\
\hline wine fraud & fruit wine & red wine & to make wine \\
\hline wine grapes & honey wine & sparkling wine & to rack wine \\
\hline wine merchant & ice wine & spiced wine & to spoil wine \\
\hline wine region & press wine & tainted wine & to store wine \\
\hline wine trade & table wine & varietal wine & to taste wine \\
\hline
\end{tabular}

Examples of collocations with other terms specific to these domains are: primary fermentation, malolactic conversion, filtration process, microbial stabilisation, budding knife, bench grafting, graft union, berry set, fermented grapes, grape berry, grape growing, grape juice, noble grapes, seedless grapes, table grapes, bush training, cane pruning, head training, training system, bunch of grapes, American vine, established vine, old vine, potted vine, vine guard, vine row, vine spacing, terraced vineyard, vineyard management, biodynamic viticulture, organic viticulture, sustainable viticulture, low-input viticulture, cool-climate viticulture, bladder press, bottle sealing wax, conveyor belt, vibrating sorting table and many others.

\section{Vocabulary teaching strategies}

While we established previously that the complexity of their professional duties will require the learners to master all four skills, the ESP class may aim to develop some skills more than others and this choice depends on certain factors 
most important among them being the students' proficiency level, their priority needs and also which of the four skills ensures the most vocabulary exposure. So, the purpose is to teach specialized vocabulary in an efficient and engaging manner, to ensure high levels of retention and create the skills for ongoing learning, but the conditions are not always ideal for all these requirements to be met. Any type of strategy should take into account the important steps of how vocabulary is introduced, but also how it is practiced, repeated and revised to ensure retention. In other words,

Lexical items can be, in theory, learned de-contextualised, but it does not ensure mastery of the item. Contextualised learning is preferable, because learning vocabulary is not a simple memorisation of lexical phrases. They must be integrated into the learner's linguistic resources so that they are spontaneously available when needed. Vocabulary $u s-$ age is not the same as its knowledge. And it is a teacher's job to activate these items in a classroom. This means that learners must process this newly acquired vocabulary. Therefore, a logical follow-up is a multi-step procedure: 1) checking comprehension of authentic passages; 2) providing more practice; 3) revision and 4) consolidation. (Kavaliauskienë \& Janulevièienë, 2000)

It goes without saying that, regardless of methods and techniques, it is particularly important in ESP that the materials be authentic and the learning contextualized, as advised above. There is such a considerable amount of research that advocates for the use of a corpus of authentic texts in ESP that it has become a standard (Lee, 1995; Blagojević, 2013; Wu, 2014; Hou, 2014) and I will not insist on this topic except to say that using corpora is invaluable, especially for the detection and understanding of collocations specific to the field (Dudley-Evans and St John 1998, pp. 84-85) which can then be corrected by using methods such as Tim Johns' concordancer program, for example (Gabrielatos, 2005).

The materials can be more general or more focused depending on how much these domains are prioritized during the ESP class, depending on whether the students are enrolled in the horticulture program and learn about viticulture and winemaking marginally or their program is entirely focused on this branch of horticulture. My experience has been the former, therefore, I tried to offer the students the basics, the most common specialized vocabulary encountered in this field, on levels of specialization. The students should know, for example, the English equivalents for basic concepts about the plant as well as its cultivation and uses such as grapevine, grapes, vineyard, plant, leaf, seed, wine and other similar sub-technical or semi-technical terms that are known and used in everyday speech by non-specialists as well. A second level would go deeper into the discipline, to terms that are not commonly used in everyday conversation and more specific to the wider horticulture domain in general but also to the 
viticulture one in particular, such as planting, harvesting, irrigation, spraying, viticulturist, vine, winemaking, winery etc. The third level would constitute terms that are specific to and highly used in viticulture and winemaking such as cane, spur, trellis, training system, yeast, primary fermentation, fining, free run, etc. Going through all the levels should occur regardless of the proficiency level, but the more advanced the level, the more specialized words we will be able to teach and the learners to retain.

Introduction of new vocabulary is most often done by means of the two receptive skills, reading and listening, while the practice is accomplished through the productive skills, writing and speaking. The corresponding activities should be modulated according to the proficiency level.

My experience has taught me to employ variety in order to prevent monotony and diversify the approach. The actual conditions of the class matter very much and sometimes the students appreciate a more monotonous or focused type of activity, other times they may find interaction and diversity more conducive to learning. It depends on the time of the day the ESP class is scheduled, how tired or hungry the students are, their state of mind, what disciplines they had before and how exhausting they were, and many other factors. It is, again, the task of the ESP teacher to be flexible and adapt.

Reading and listening are the usual starting points for related vocabulary activities. The choice of material is, again, according to the proficiency level of the students, but the topics can be found in a wide variety. In terms of reading materials, my choice has normally been from the practical side of viticulture and winemaking, therefore I chose fragments that discussed cultivation techniques or general grape processing techniques so that the basic concepts can be encountered. In order to make the activity efficient, less time-consuming and focused on the chosen topic, it is advisable that the texts be adapted, shortened or compiled from different fragments so that the result can be easily assimilated by the learners, with concentrated terminology and not exceedingly long. I used a variety of sources, from books (e.g. Lon Rombaugh's The Grape Grower, 2002.) to encyclopedia articles (www.britannica.com) and other dedicated websites such FAO, viticulturists' blogs and sites detailing life in a vineyard or wine magazines (www.winespectator.com) depending on the target vocabulary. The magazine articles are generally reviews of wine or wineries and therefore contain more general vocabulary with a smaller percentage of highly technical terms because their intended audience is the general public as well as the connoisseurs. These are also helpful for taste descriptors, but such terminology goes too far into a niche. For more advanced learners, even scientific articles can be used as they also increase their contact with academic English. However, in my experience, working with intermediate or lower-intermediate students, I normally used books or magazine articles about viticulture and winemaking. 
The text is then the starting point for vocabulary activities. The students are given definitions / descriptions (Kadagidze and Tskhvitava, 2015, p. 18) or the L1 equivalent and they have to find the terms in the text. Then other exercises such as matching with definition or with an image, fill in gaps, derivation practice, hangman, crossword puzzles and others can be used to encourage practice and consolidation of the specialized terminology. In terms of reading, it is worth mentioning here the findings of research about intensive reading or sustained silent reading. It "refers to reading short texts thoroughly and with clear goals" (Koay, 2015) and it helps with comprehension and meaning but also with vocabulary. It requires effort and focus, it has clear goals and, when carefully planned and implemented, it is very useful for the acquisition of new vocabulary (Macalister, 2011; Cotoc, 2019; Khazaal 2019).

In terms of listening materials, the criteria are the same as the ones for reading materials when it comes to topics and type of vocabulary. YouTube offers a myriad of video material, from short videos about cultivation techniques (propagation, planting, pruning, training, general vineyard care, harvesting, processing, vinification techniques and others) to longer documentaries about wine regions or famous wineries. TedEd also has good educational videos from many fields but maybe not such a wide variety in the horticulture field. In order to be useful and efficient, the videos chosen for classroom use should be somewhere between three and six minutes long, the speakers should speak clearly, without an accent, and ideally slowly, characteristics that are particularly necessary in the case of students with lower proficiency level. The sound should have a good quality and should not be smothered by ambient noises or music. The video or audio file can be used either for comprehension practice or it is given to the students as a text with gaps and they will fill in the gaps with the words or phrases they hear in the audio recording. The new terminology is part of the text/audio file which can then be used just like the reading text described previously, as a starting point for a wide variety of vocabulary activities.

It is useful to mention at this point the value of incidental vocabulary learning, mainly through listening. Several studies investigated this possibility and concluded that there is value in it. The premise is that if the text/audio file is interesting for the learners in terms of content, the language is acquired subconsciously or incidentally (Danilina \& Shabunina, 2020, p. 18). In the case of video recordings, the combination between seeing the words in L1 (e.g. subtitles) and hearing them pronounced at the same time proved successful in a study that tested vocabulary retention from listening to mobile vocabulary lessons during physical activity: "Multiple instances of listening to the vocabulary with L1 L2 translation and the subsequent pronunciation of it while performing physical actions allows students to create not only receptive, but also reproductive skills of L2 translation and communication. This way of vocabulary acquisition activates implicit memory." (Zubenko \& Shwedel, 2019, p. 91). Other studies 
testing the acquisition of new words when watching a TV program with L1 subtitles or captions in class emphasized a small impact and a small number of words learned (Peters, Heynen \& Puimège, 2016, p. 146). However, there may not be enough time to do such activities in class, therefore, as an extra activity for self-study, it can prove useful, even if the gain is small. Students studying viticulture and winemaking can benefit from such activities as part of their individual study time. The teacher can recommend an appropriate selection of films or documentaries with good L1 subtitles, but there is a rather wide collection of such video files on various platforms from YouTube to Curiosity Stream, which also provide subtitles in L1. When the students themselves choose what to watch, this gives them an opportunity to employ critical thinking and check what they hear, which is something the teachers should encourage.

Brainstorming, the typical icebreaker, can sometimes be used to introduce new vocabulary, with the aid of L1, as a reminder of previous vocabulary and connection to the new. Visual aids are very effective (Georgieva, 2010) and break the text routine. More arid vocabulary that may result in a too technical and rather boring text such as plant parts, farming machinery or other structures is better illustrated literally with images. A drawing of a grapevine plant, for example, can contain on the side a list of the specific terms (root system, trunk, arm, cordon, shoot, cane, spur, leaf, tendril, inflorescence, bunch of grapes) and the students are asked to match those terms with the parts of the plant numbered in the image. Other exercises can stem from this image as well (see Table 1 below), such as labeling, where the students are asked match the terms to the image and actually write the words in the picture, next to the appropriate plant part. This helps with memorization as well as spelling, especially when it comes to more difficult terms. Also, when the activity is done, the students will have a complete and helpful visual aid, with the correct terminology next to the corresponding plant part. Another technique that works both for introduction of vocabulary as well as practice and consolidation is translation. In my previous research (Chirobocea, 2018a; Chirobocea, 2018b) I have often advocated for the use of translation in ESP even though the Communicative Approach has made us apprehensive about using L1 and translation. However, in ESP, translation used as a technique in focused and contextualized activities can be very useful and creates positive results. I will not elaborate on this at this point as I have described this approach in detail in the research mentioned above, but I will offer an example. The stages of winemaking can be introduced by short L1 sentences to be translated into L2 and a follow-up activity can ask the students to match short definitions to the new terminology discovered in the previous translations (see Table 2 below). 
Table 1. Example of vocabulary activity involving visual aids.
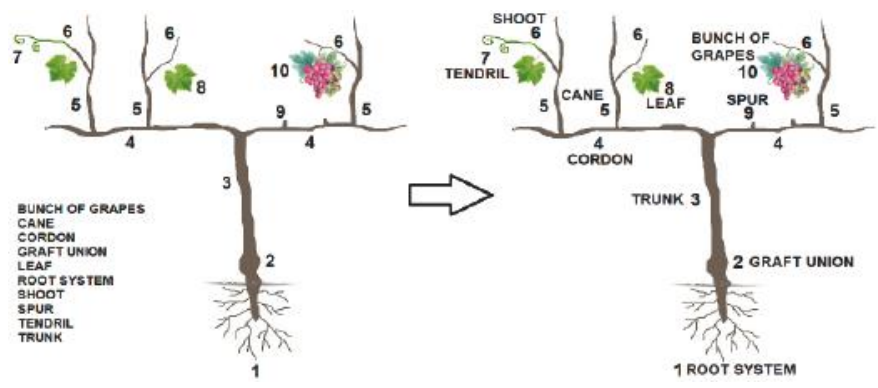

Follow-up exercise. Fill in the blanks with terms from the image above:

1) S... are the small segments left on a c... after the c... are pruned in autumn or winter.

2) The b... of grapes develop on c... and s... and are harvested in autumn.

3) The $g . .$. is a bulge on the t..., just above the r... .

4) T... are modifications of the stem and help the plant cling onto a support.

(Scheme and activities created by the author)

Table 2.

Example of vocabulary activity involving translation exercises.

The underlined terms represent the target terminology

$\underline{\text { Recoltarea. }}$ Când sunt destul de copți și conțin cantitatea optimă de zahăr, strugurii sunt recoltaţi atât mecanic cât şi manual.

Desciorchinarea și zdrobirea. Desciorchinarea este procesul de separare a boabelor de rahis iar zdrobirea implică stoarcerea uşoară şi ruperea pieliței boabelor pentru a elibera sucul din bace.

Fermentația primară. Drojdia este în mod normal prezentă deja pe struguri şi ajută la fermentația primară în procesul de vinificație.
Harvesting. When they are ripe enough and contain the optimal amount of sugar, the grapes are harvested both mechanically and by hand.

Destemming and crushing.

Destemming is the process of separating the grapes from the rachis while crushing involves gentle squeezing and the breaking of the grape skins to release the juice from the berries.

Primary fermentation. Yeast is normally already present on the grapes and helps with primary fermentation in the winemaking process. 
Presarea reprezintă aplicarea presiunii asupra strugurilor pentru a separa sucul de pielițe.

Limpezirea și filtrarea. Agenții de limpezire sunt folosiţi pentru a diminua taninul şi a elimina particulele care pot tulbura vinul. Scopul filtrării este clarificarea şi stabilizarea microbiană.
Pressing represents the application of pressure on the grapes to separate the juice from the skins.

Fining and filtration. Fining agents are used to diminish tannin and to eliminate particles that can cloud the wine. The purpose of filtration is clarification and microbial stabilization.

Follow-up exercise. Use the previous translation exercise to find the correct terms that fit the definitions given:

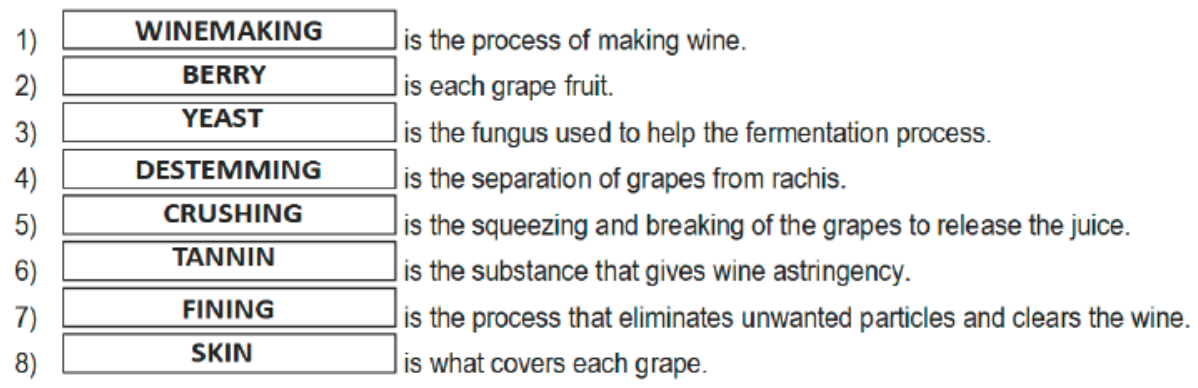

(Scheme and activities created by the author)

Practice, consolidation and revision of the new vocabulary are very important stages, especially for ESP students because they are either not very interested in learning English or simply do not have contact with the English language outside the ESP class, as other researchers point as well:

Revision and consolidation are a required part of the process of vocabulary acquisition. The process of forgetting is very fast. According to research on memorising, a human being forgets 80 per cent of new information in 24 hours. It might sound exaggerated, but there is some truth in it, though these figures are different for different people. But the fact remains that the less a person is interested in something, the faster the process of forgetting is. Thus, revision and consolidation must take place after a lapse of time. (Kavaliauskienë \& Janulevièienë, 2000)

There are many ways in which specialized vocabulary can be practiced and revised. An effective one, which I detailed in my previous research specifically about the horticulture syllabus (Chirobocea, 2018c, pp. 167-168), is to always keep the terminology fresh, to organize the topics covered over a semester or a year so that the vocabulary is related and always repeated from one lesson to 
the next, with more additions every time. When the topics are related to one particular field, such as viticulture, it is in fact very difficult to avoid repeating the terms. Thus, if the topics flow from one week to the next through cultivation techniques, climate and soil, propagation methods, planting, training systems, pruning systems, activities in a vineyard, growth stages of the grapevine, harvesting, processing methods, winemaking stages etc. it is impossible not to go through many of the terms almost every week because we cannot talk about pruning without mentioning canes, shoots and spurs, or irrigation without elements of soil and weather and so on. This ensures that the terminology is constantly revised, the students see, hear and produce the terms regularly over the course of a semester or a year.

There are many techniques that can achieve this goal of constant repetition and consolidation, and variety ensures retention as well as avoidance of monotony. Learning lists of words is not exactly a favorite or efficient method, although some researchers found it can work (Yamamoto, 2014). The same types of activities mentioned previously (various types of matching, gap filling, derivation exercises, error correction, hangman and crossword puzzles as well as short translations) are very effective and ensure diversity. However, they still keep the learners in a rather restricted and safe environment where they accomplish activities according to a pattern.

At this point it is worth mentioning the issue of receptive versus productive vocabulary because learners may know the meaning of many more terms than they can actually produce in written or spoken language. This imbalance results in poor performance in terms of productive skills. Knowing the meaning of a term is not the same as understanding usage, therefore the productive skills are a good way of consolidating vocabulary and of transferring knowledge from the receptive into the productive area. This is problematic because students are usually very apprehensive about writing and even more about speaking, especially at lower levels of proficiency, but ESP teachers should be encouraging and persist in getting the learners out of their shells. Writing tasks can range from short answers to questions related to a reading or listening activity to longer descriptive, argumentative or expository texts. It is easier, especially for lower levels of proficiency, to start with descriptions, simple texts where the students are encouraged to use simple sentences, the present tense, and as much vocabulary as they know, gradually increasing complexity as they build confidence and their knowledge increases. Descriptive texts in this context include short descriptions (prompted by a text or an image) of the grapevine plant, of a vineyard, of the main stages of cultivation, of the issues that each stage might have, of the winemaking process and the issues that each stage might have, of a winery etc. They can also describe a particular device, for example the wine press, what it is made up of and how it functions. Argumentative texts can start from a text, an image, from brainstorming, a table or graph with information 
they can interpret. Thus, they can discuss the advantages and disadvantages of cultivating grapevine (maybe compared to a different crop), of using a particular pruning or training system instead of another, of using one type of irrigation in the vineyard instead of another, of cultivating table grapes or wine grapes, of producing dry wine or sweet wine, of using manual labor or mechanization, difference between conventional and organic viticulture/ winemaking, etc.

The same topics can be used for prompted conversation, short discussions, gradually increasing complexity. Such speaking activities can start from a text, from an image or from an audio recording. Role-play activities, which are good speaking activities for more advanced students, can be either prepared in advance or impromptu and their topics can revolve around more practical topics such as organizing a wine tasting, a job interview for vineyard laborers or organizing a booth at a grape or wine fest, fair or show. While in the written tasks the learners work individually, can look up terms and have more time to polish their sentences, in the speaking activities the students feel they are put on the spot and suddenly do not remember any words. But they must not be cut off from their materials and textbooks. Even more, a list of terms can be provided for a specific speaking task, which will include the most frequent ones related to that particular topic because these are learning events, not exams and the more they see and use a terms the better.

More advanced students may benefit more from other types of activities, such as those providing task-based or project-based learning, which are more complex, involve team work, more effort and different strategies, and include all the steps of vocabulary teaching: introduction (the learners discover and look up the terminology themselves), practice and revision (they will use the terminology many times during the preparation of their projects). In fact, such activities have proven much more successful for vocabulary acquisition than the traditional approach in ESP (Jurčenko, 2015; Sarani \& Sahebi, 2012) as well as "increased confidence, enjoyment and motivation among learners" (East, 2017). They also function to expose the learners to situations they will likely deal with in their future careers (Vukićević-Đorđević, 2019, p. 296). The domains of viticulture and winemaking are particularly prone to this type of activities and the students can develop other useful skills during the course of preparing for complex tasks such as researching a topic, working in teams, selecting and synthesizing information, making presentations, developing critical thinking, debating on issues and bringing arguments. Possible topics can include the one mentioned previously for the writing and speaking activities, but also: 


\begin{tabular}{|c|c|}
\hline Topics & $\begin{array}{l}\text { Advice on what the students should take into account } \\
\text { for presentations or projects }\end{array}$ \\
\hline $\begin{array}{l}\text { The best irrigation } \\
\text { pattern in a } \\
\text { vineyard }\end{array}$ & $\begin{array}{l}\text { advantages and disadvantages of various types of } \\
\text { irrigation (sprinkler, surface, drip) } \\
\text { topography } \\
\text { costs, installation, equipment } \\
\text { ecological and efficiency issues }\end{array}$ \\
\hline $\begin{array}{l}\text { The best solutions } \\
\text { for fertilization in a } \\
\text { vineyard }\end{array}$ & $\begin{array}{l}\text { what nutrients does grapevine need more? } \\
\text { types of fertilizers and distribution } \\
\text { chemical or organic fertilizers? } \\
\text { other solutions for fertilization in a vineyard }\end{array}$ \\
\hline $\begin{array}{l}\text { The best solutions } \\
\text { for pest control in a } \\
\text { vineyard }\end{array}$ & $\begin{array}{l}\text { common grapevine pests } \\
\text { pests depending on location (climate, topography, } \\
\text { country) } \\
\text { chemical or organic pesticides? } \\
\text { alternatives to chemical pesticides }\end{array}$ \\
\hline $\begin{array}{l}\text { Solutions for grape } \\
\text { harvesting and } \\
\text { processing }\end{array}$ & $\begin{array}{l}\text { preparation, time of the year } \\
\text { hiring workforce } \\
\text { mechanization or manual labor? } \\
\text { buying equipment (examples) }\end{array}$ \\
\hline $\begin{array}{l}\text { Promotion of } \\
\text { organic viticulture }\end{array}$ & $\begin{array}{l}\text { what are the advantages and disadvantages? } \\
\text { it is sustainable? } \\
\text { what does it involve from the practical point of view? } \\
\text { use convincing arguments }\end{array}$ \\
\hline
\end{tabular}

Extra material is important and should be provided for self-study. This helps the students learn at their own pace, interact with original material, different from the one discussed in the classroom, test themselves, improve retention as well as the volume of vocabulary they acquire, whether it is general or technical. This extra material can be easily created and made available online, on platforms such as Moodle, Google Classroom, Wakelet, Kahoot and others. Self-assessment tests can be created on Google Forms and the students can see their results immediately. Flashcards can be created on sites such as https://flashcard.online/ 
and uploaded as pdf. files on any online platform. Also, as mentioned earlier, links to audio or video files for fun and further learning can also be provided on any chosen platform. Glossaries of the terminology taught in class, with L1 equivalents, are also a useful tool for revision and self-testing.

\section{Conclusion}

This has been an overview of the characteristics of viticulture and winemaking vocabulary, with a perspective on the variety of techniques that can be employed to teach it. The use of authentic materials, multimodality and multimedia adapted to the specificities of this type of vocabulary can lead to the successful acquisition of terminology through various activities that also encourage the development of the four skills as well as critical thinking and skills for ongoing learning outside the ESP class. Adapted to the learners' language proficiency and domain-specific knowledge, techniques such as reading or listening and the activities stemming from them, as well as translation, writing, role-play and task-based activities can introduce, practice, consolidate and revise both general and technical vocabulary. Less researched techniques such as intensive reading or incidental learning from video or audio means should not be disregarded either because they may prove helpful for vocabulary gain as well as introduce variety. The activities can be easily adapted to the language of horticulture in general or viticulture and winemaking in particular as they offer a wide range of topics to be explored. It is also highly recommended to make use of online resources such as material in digital format and online platforms which are particularly useful and more rapidly available to learners who can exploit them for further learning and self-testing.

\section{References}

Adam, S. L., Stan, R. S., Moangă, A. S., \& Oroian, E. (2013). Challenges Faced When Teaching English for Specific Purposes. Bulletin UASVM Horticulture, 70(2), 425-429.

Atkinson, D. (1993). Teaching Monolingual Classes. London: Longman.

Blagojević, S. (2013). Original Texts as Authentic ESP Teaching Material - The Case Of Philosophy. ESP Today, 1(1), 113-126.

Brezina, V., \& Gablasova, D. (2015). Is There a Core General Vocabulary? Introducing the New General Service List.AppliedLinguistics, 36/1, (published August 2013), 1-22, https://doi.org/10.1093/applin/amt018, Retrieved July 2021 from https://academic.oup.com/applij/article/36/1/1/226623?login=true 
Brooks, M. (2014). The Role of Vocabulary in English for Specific Purposes (ESP) Teaching and Learning: Considerations for Asia University. Retrieved June 2021 from https://core.ac.uk/download/pdf/72791573.pdf.

Browne, C. (2013). The New General Service List: Celebrating 60 years of Vocabulary Learning. The Language Teacher, 37(4), 13-16.

Chirobocea, O. (2018a). A Case for the Use of Translation in ESP Classes. Journal of Languages for Specific Purposes, 5/2018, 67-76.

Chirobocea, O. (2018b). Translation as Language Learning Technique and the Use of L1 in ESP Classes. Learners' Perceptions. "Ovidius" University Annals, Economic Sciences Series, XVIII(2), 221-227.

Chirobocea, O. (2018c). Vocabulary Acquisition in ESP. Perspectives, Strategies and Resources. Studii şi cercetări filologice. Seria limbi străine aplicate, 17/2018, 171-180.

Costeleanu, M. (2019). The Role Of Vocabulary in ESP Teaching. The European Proceedings of Social \& Behavioural Sciences, 67, 996-1002.

Cotoc, A. (2019). Languages for Specific Purposes and Sustained Silent Reading. A New Challenge for the Millennial Students. The Annals of "Ovidius" University of Constanța: Philology Series, XXX(1), 57-66.

Coxhead, A. (2013). Vocabulary and ESP. In. B. Paltridge \& S. Starfield (Eds.), The Handbook of English for Specific Purposes (pp. 115-132), West Sussex: John Willey \& Sons Inc.

Danilina, S., \& Shabunina, V. (2020). Intentional vs. Incidental ESP Vocabulary Acquisition by Political Science Students. Advanced Education, 16, 18-27.

Dudley-Evans, T., \& St John, M. (1998). Developments in English for Specific Purposes. UK: Cambridge University Press.

East, M. (2017). Research into practice: The task-based approach to instructed second language acquisition. Language Teaching, 50(3), 412-424.

Gabrielatos, C. (2005). Corpora and language teaching: Just a fling or wedding bells? Teaching English as a Second Language - Electronic Journal, 8/4. Retrieved June 2021 from https://files.eric.ed.gov/fulltext/EJ1068106.pdf

Gatehouse, K. (2001). Key Issues in English for Specific Purposes (ESP) Curriculum Development. The Internet TESL Journal, VII(10). Retrieved June 2021 from http://iteslj.org/Articles/Gatehouse-ESP.html

Georgieva, V. (2010). Teaching Terms Effectively. ESP Conference: Annual Bulgarian English Teachers' Association Conference (Veliko Turnovo). ISSN 1311-7351. Retrieved June 2021 from https://www.beta-iatefl.org/1638/blogpublications/teaching-terms-effectively-in-esp/ 
Hou, H. (2014). Teaching Specialized Vocabulary by Integrating a CorpusBased Approach: Implications for ESP Course Design at the University Level. English Language Teaching, 7, 26-37.

Jurčenko, A. (2015). Applying task-based language learning method for teaching vocabulary. Rural Environment. Education. Personality. (REEP). Proceedings of the International Scientific Conference (Latvia), 8/2015, 423-428.

Kadagidze, L., \& Tskhvitava, T. (2015), Activities of Teaching Vocabulary in Agriculture ESP. Proceedings of the IX European Conference on Education and Applied Psychology (Vienna, Austria), 12-20. Retrieved July 2021 from https://www.academia.edu/32312374/Section_2_Activities_of_Teaching _ Vocabulary_through_Receptive_and_Productive_Skills_in_Agriculture_ ESP?auto $=$ download

Kavaliauskienë, G., \& Janulevièienë, V. (2001). Using the lexical approach for the Acquisition of ESP vocabulary. The Internet TESL Journal, VII(3). Retrieved June 2021 from http://iteslj.org/Articles/Kavaliauskiene-LA.html

Khazaal, E. N. (2019). Impact of Intensive Reading Strategy on English for Specific Purposes College Students' in Developing Vocabulary. Arab World English Journal, 10 (2), 181-195.

Koay, J. (2015). What is Intensive Reading? Retrieved June 2021 from https:// www.edumaxi.com/what-is-intensive-reading/

Kovács, G. (2011). ESP for Horticulture - Needs Analysis and Genre Analysis. Terminology and Translation Studies. Plurilingual terminology in the Context of European Intercultural Dialogue, 285-296. Retrieved July 2021 from https://www.academia.edu/35988835/ESP_for_Horticulture_-Needs_ Analysis_and_Genre_Analysis

Lee, W. (1995). Authenticity revisited: Text authenticity and learner authenticity. ELT Journal, 49(4), 323-328.

Lewis, M. (1997). Implementing the Lexical Approach. Language Teaching Publications.

Macalister, J. (2011). Today's teaching, tomorrow's text: exploring the teaching of reading. ELT Journal, 65(2), 161-169.

MacNeil, K. (2015). Wine Bible. New York: Workman Publishing.

Peters E., Heynen, E., \& Puimège, E. (2016). Learning vocabulary through audiovisual input: The differential effect of L1 subtitles and captions. System 63, 134-148.

Rombaugh, L. (2002). The grape grower. Chelsea Green Pub.

Sarani, A., \& Sahebi, L.F. (2012). The Impact of Task-based Approach on Vocabulary Learning in ESP Courses. English Language Teaching, 5(10), 118-128. 
Vukićević-Đorđević, L. (2019). Making The Most of Experience: from Syllabus to Textbook Design. The Journal Of Teaching English For Specific and Academic Purposes, 7(3), 293-302.

Vulić, V. (2013). A framework for development and implementation of an ESP course for students of agriculture. 48th Croatian \& 8th International Symposium on Agriculture (Dubrovnik, Croatia), 865-869. Retrieved July 2021 from http://sa.agr.hr/pdf/2013/sa2013_p0810.pdf

Woodward-Kron, R. (2008). More than just jargon - The nature and role of specialist language in learning disciplinary knowledge. Journal of English for Academic Purposes, 7, 234-249.

Wu, L-F. (2014). Motivating College Students' Learning English for Specific Purposes Courses through Corpus Building. English Language Teaching, 7(6), 120-127.

Xhaferi, B. (2009). Teaching and learning ESP vocabulary. Revista de Lenguas para Fines Especificos, 15/16, 229-255.

Zubenko, T., \& Shwedel, A. (2019). Integrating mobile listening and physical activity to facilitate intentional and incidental vocabulary acquisition. Advanced Education, 11, 84-92.

Yamamoto, Y. (2014). Multidimensional vocabulary acquisition through deliberate vocabulary list learning. System 42, 232-243. 